\title{
Pelatihan Komunikasi Krisis Masyarakat Lokal dalam Mengelola Keluhan Wisatawan saat Pandemi Covid19 untuk Pengembangan Destinasi Wisata Kampung Lama Paluh Naga di Desa Denai Lama Kecamatan Pantai Labu
}

\author{
Faustyna*, Rudianto, Puji Santoso \\ Fakultas Ilmu Sosial Ilmu Politik, Universitas Muhamadiyah Sumatera Utara, Medan, Indonesia \\ *Coresponding Author : faustyna@umsu.ac.id \\ Dikirim: 20-06-2021 ; Direvisi: 18-08-2021 ; Diterima: 28-08-2021
}

\begin{abstract}
Abstrak: Pengabdian Kemitraan Masyarakat ini bertujuan untuk memberikan pelatihan komunikasi krisis terkait menangani keluhan wisatawan kuliner Paluh Naga saat pandemic covid19 sebagai edukasi dan berdampak pada ekonomi masyarakat Desa Denai Lama Kecamatan Pantai Labu. Tahapan-tahapan dalam kegiatan ini adalah (1) pemberian materi; (2) Pendampingan komunikasi krisis pokus pada saat pelaksanaan menangani keluhan pelanggan; (3) Evaluasi saat kegiatan dilakukan. Kegiatan ini dilakukan untuk membantu dan mengenalkan komunikasi krisis masyarakat dalam menangani keluhan para wisatawan yang berkunjung di lokasi wisata kuliner Paluh Naga Kecamatan Pantai Labu Kabupaten Deliserdang agar para pelaku usaha wisata di lokasi wisata kuliner Paluh Naga memiliki ketrampilan dalam hal menangani keluhan wisatawan sehingga dapat berkontribusi untuk pengembangan destinasi wisata kuliner Paluh Naga yang dapat meningkatkan reputasi desawisata Denai Lama Paluh Naga. Luaran yang didapat dalam Pengabdian Kemitraan Masyarakat ini adalah menghasilkan suatu pola Teknik menangani keluhan wisatawan secara effectively.
\end{abstract}

Kata Kunci: komunikasi krisis; keluhan wisatawan; wisata kuliner

Abstract: This Community Partnership Service aims to provide crisis communication training related to handling complaints from Paluh Naga culinary tourists during the COVID-19 pandemic as an education and impact on the economy of the people of Denai Lama Village, Pantai Labu District. The stages in this activity are (1) the provision of materials; (2) Focusing crisis communication assistance during the implementation of handling customer complaints; (3) Evaluation when activities are carried out. This activity is carried out to assist and introduce community crisis communication in handling complaints from tourists visiting the Paluh Naga culinary tourism location, Pantai Labu District, Deliserdang Regency so that tourism business actors at the Paluh Naga culinary tourism location have skills in handling tourist complaints so that they can contribute to development of the Paluh Naga culinary tourism destination which can improve the reputation of the Denai Lama Paluh Naga tourism village. The output obtained in this Community Partnership Service is to produce a technical pattern for dealing with tourist complaints effectively.

Keywords: communication crisis, tourist complaints, culinary tourism

\section{PENDAHULUAN}

Wisata Paluh Naga merupakan sebuah destinasi wisata agrowisata yang dilengkapi dengan wisata kuliner yang menyajika menu-menu tradisisonal, menu yang dari dahulu telah dinikmati orang tua kita dahulu dan telah diwariskan nenek moyang kita. Keunikan dari menu yang disajikan dengan harga yang kompetetitif memicu hadirnya para wisatawan lokal yang sangat antusias. Hal ini yang membuat

@ 2021 JagoMipa (https://bimaberilmu.com/jurnal/index.php/jagomipa) 
wisata Paluh Naga mendadak popular dikalangan para wisatawan lokal. Paloh Naga sendiri digunakan sebagai nama agrowisata setelah melalui diskusi para deklarator destinasi wisata yang memiliki luas 35 hektar dan memiliki tempat yang sangat potensi yang akan dikembangkan tempat wisata ini memiliki indahnya Sunrise (matahari terbit) ataupun sunset (mata hari tenggelam) sayangnya banyak masyarakat yang belum mengenal tempat ini.

Wisata Paluh Naga Desa Denai Lama Kecamatan Pantai Labu ini memiliki beberapa spot wisata yaitu, Sanggar Lingkaran, Agrowisata Paloh Naga dan Kuliner lokal. Letak lokasi wisata Paluh Naga ini persis di desa Denai Lama Kecamatan Pantai Labu Kabupaten Deli Serdang. Wisata Kampung lama Paluh Naga dibentuk dengan melibatkan para pemerintah Desa setempat dan stakeholder untuk membangun citra pariwisata di Kabupaten Deli Serdang. Wisata kampung lama Paluh Naga diresmikan pada hari Minggu tanggal 20 January 2021 oleh Bapak H Ashari Tambunan selaku Bupati aktif Kabupaten Deliserdang secara langsung Desa Wisata Kampoeng Lama di Desa Denai Lama Kecamatan Pantai Labu,Kabupaten Deli Serdang. Meski sudah ditetapkan sebagai destinasi wisata Kampung lama Paluh Naga akan tetapi dalam pelaksanaan dilapangan semakin populernya wisata Paluh Naga ini, namun destinasi wisata ini mengalami beberapa aktivitas yang dapat mengakibatkan penyebaran virus Covid19, hal ini dapat dibuktikan dengan adanya tingkat kunjungan yang tinggi sehingga wisatawan hadir dengan keadaan bertumpuktumpuk dan relative tidak memperhatikan protokol Kesehatan. Sehingga wisatawan mengeluhkan keadaan yang dapat mengkhawatirkan para wisatawan apalagi kesediaan air untuk mencuci tangan terbukti sudah habis. Wisatawan yang tidak mematuhi prokes yang telah ditetapkan seperti aktivitas wisata yang telah terjadi pada setiap hari minggu saat wisatawan berkunjung dengan tidak menggunakan protokol Kesehatan dan pihak pelaku wisata tidak dapat konsisten untuk menyediakan air dan sabun cuci tangan.

Masyarakat setempat melakukan aktivitas-aktivitas sebagai pelaku wisata kuliner bersama petugas pemerintah Desa relative mengabaikan keluhan wisatawan yang mengalami kekhawatiran saat berkunjung dengan kondisi wisatawan berpikir realtif tidak aman saat berwisata di Paluh Naga wisata. Asumsi penulis bahwa pelaku wisata atau masyarakat sekitar pelaku usaha wisata tidak peduli dengan keadaan ini atau memang tidak memahami bagaimana menghadapi keluhan pelanggan. Selain itu juga ketidaktegasan aparat pemerintah dalam mengimplementasikan surat keputusan yang telah ditetapkan untuk mematuhi prokes bagi para wisatawan.

Wisata Paluh Naga sampai saat ini masih popular dan ramai dikunjungi wisatawan lokal. Sehingga dibutuhkan upaya dialog secara persuasive untuk mengkondusifkan suasana wisata Paluh Naga yang saat ini menuai kekawatiran dan perhatian para wisatawan. Sehingga membutuhkan kontribusi masyarakat untuk membantu mengantisipasi keluhanm wisatawan dalam situasi krisis pandemi Covid19. Oleh karena itu, Pimpinan Desa kepala Desa Lembaga Bumdes dan para lembaga terkait termasuk Dinas Pariwisata Kabupaten Deliserdang selain berpartisipasi pada Pelestarian dan Pengembangan wisata Paluh Naga juga dibutuhkan kontribusinya pada sosialisasi dan menyuluhan tentang pemahaman mengelola keluhan wisatawan melalui komunikasi krisis terkait menangani keluhan wisatawan dapat melakukan antisipasi sebelum, saat dan setelah krisis pandemi covid19 dan pemahaman untuk kedisplinan menggunakan Prokes. Sesuai yang 
dikatakan (Setiawan, p. 12) Keluhan wisatawan selain dari Prokes juga atribut papan nama jalan untuk mempermudah jangkauan wisatawan ke lokasi wisata.

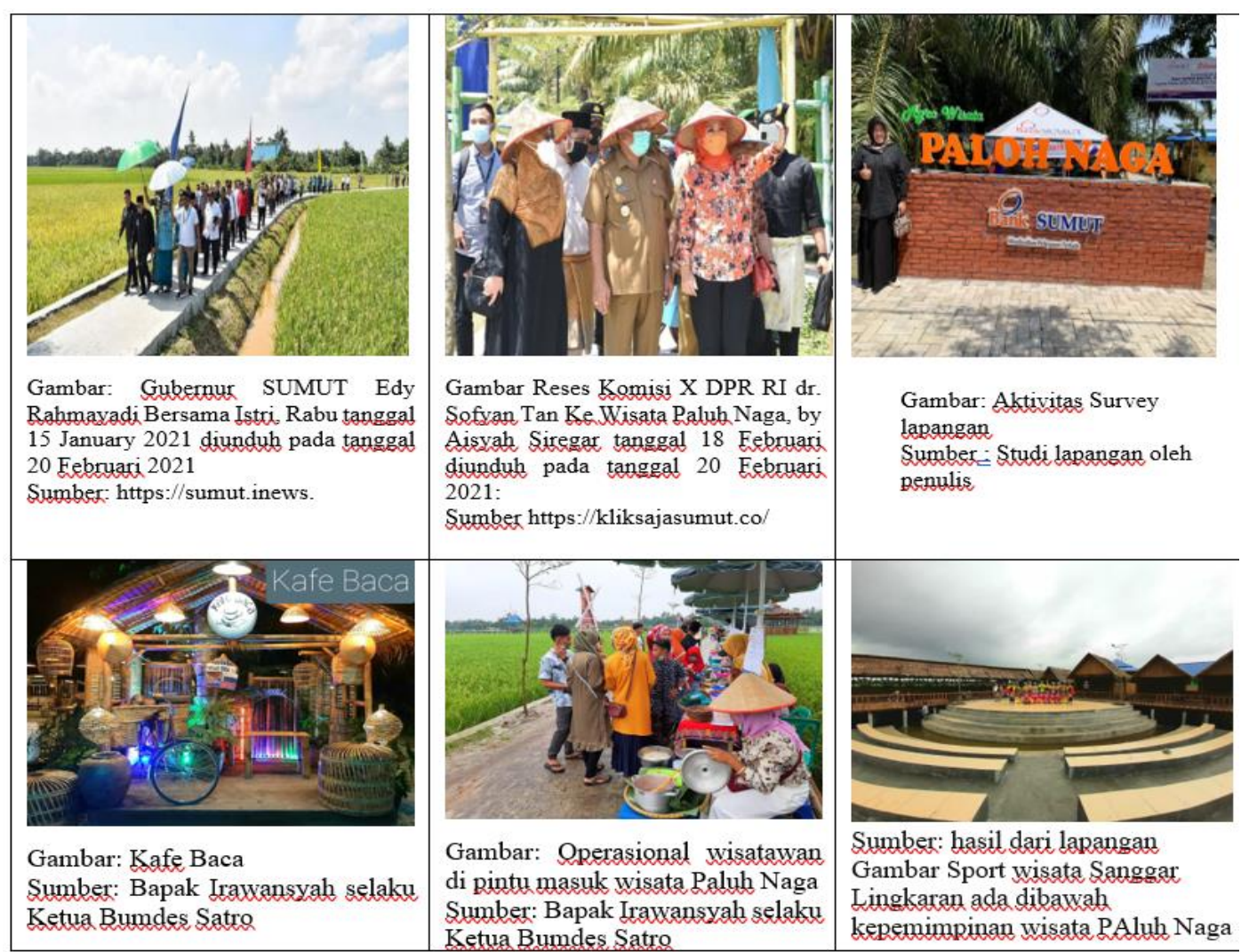

Gambar 1. Destinasi Wisata Kampung Lama Paluh Naga di Desa Denai Lama Kecamatan Pantai Labu

\section{METODE PELAKSANAAN KEGIATAN}

Metode yang digunakan dalam kegiatan Program Rekayasa Sosial dan Karya Seni adalah dengan metode Partisipatory Rural Appraisal (PRA). Metode ini mengakomodasi kepentingan masyarakat dan melibatkan masyarakat untuk merancang tindakan yang meliputi rencana, pengawasan, dan evaluasi pengaruh atau dampak bagi kehidupannya (Adimihardja: 2003). Beberapa prinsip dasar yang harus dipenuhi dalam metode PRA antara lain: saling belajar dan berbagi pengalaman, keterlibatan semua anggota kelompok dan informasi, orang luar sebagai fasilitator, konsep triangulasi, serta optimalisasi hasil, orientasi praktis dan keberlanjutan program (Rochdyanto: 2000).

Metode kegiatan Program Kemitraan Masyarakat ini dituangkan dalam tahapan pelaksanaan seperti pada Gambar 2. 


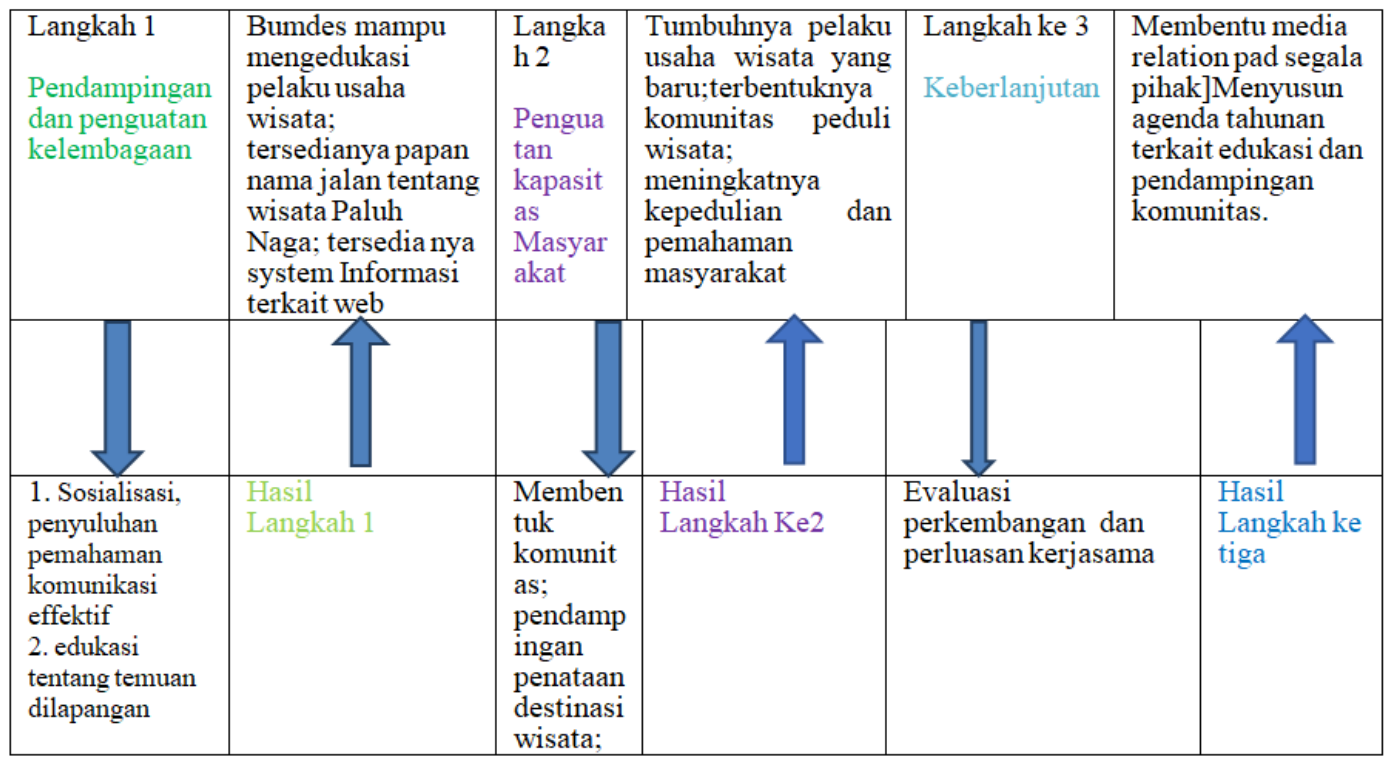

Gambar 2. Metode kegiatan Program Kemitraan Masyarakat yaitu

Pengabdian Kemitraan Masyarakat ini dilakukan dengan beberapa tahapan

1. Tahapan pertama adalah dengan melakukan Pendampingan dan penguatan kelembagaan yang meliputi a) Sosialisasi, penyuluhan pemahaman komunikasi effektif; b). edukasi tentang temuan dilapangan

2. Tahapan kedua adalah melakukan pelatihan penanganan keluhan wisata sehingga menghasilkan Penguatan kapasitas Masyarakat dengan melakukan pelatihan komunikasi krisis terkait keluhan wisatawan dengan membentuk komunitas; pendampingan penataan destinasi wisata; 2.1. Memahami Masalah a). dengan mendengarkan masalah wisatawan; b) berikan kesempatan pada pelanggan untuk menjelaskan masalah tanpa gangguan; c) Jangan menantang keluhan mereka; Ajukan pertanyaan untuk mengklarifikasi masalah dan penyebabnya; d) Hubungkan pelanggan dengan orang lain jika diperlukan;. 2.2 Menyelesaikan Masalah; a) minta maaf dengan tulus: b) Berempatilah dengan masalah mereka; c) Cari tahu bagaimana pelanggan ingin menyelesaikan masalah; d) Yakinkan mereka bahwa masalah akan teratasi; e) Lakukan yang terbaik untuk mengatasi keluhan; f) Berterimakasihlah kepada pelanggan: g) Hubungi mereka; h) Rekam atau catatlah data interaksi pelanggan; 2.3 Mengikuti panduan umum; a) Rekam atau catatlah data interaksi pelanggan; 2.4. Mengikuti panduan umum. 2.5. Ada beberapa hal yang tidak dianjurkan dikatakan, a) Berdasarkan kebijakan kami, b) saya akan menyambungkan kepada manager kami

3. Tahapan ketiga adalah Evaluasi pengembangan dan perluasan kerjasama yang dilakukan dengan meminta respon dan saran untuk keberlanjutan usaha wisata ini serta manfaat dari kegiatan PKM yang telah dilakukan. Hal ini dijadikan sebagai bahan kajian bagi tim PKM dalam rangka penyebarluasan pentingnya pemahaman Teknik menangani keluhan pelanggan khususnya para pelaku usaha wisata di Wisata Kuliner Paluh Naga Desa Deani Lama 


\section{IMPLEMENTASI KEGIATAN}

PKM pelatihan kounikasi krisis terkait menangani keluhan pelanggan bagi para pelaku usaha wisata di desa Denai Lama Paluh Naga memiliki beberapa tahapan pelaksanaan. Tabel 1 menjelaskan tentang pelaksanaan dalam kegiatan PKM.

Tabel 1. Tahapan Kegiatan PKM

\begin{tabular}{|l|l|}
\hline No. & \multicolumn{1}{|c|}{ Tahapan Kegiatan PKM } \\
\hline 1 & $\begin{array}{l}\text { Pembukaan PKM- pelatihan komunikasi krisis bagi para pelaku usaha wisata kuliner ibu- } \\
\text { ibu dari masyarakat setempat desa Denai Lama Wisata kuliner Paluh Naga Kecamatan } \\
\text { Pantai Labu Kabupaten Deliserdang }\end{array}$ \\
\hline 2 & $\begin{array}{l}\text { Penyelenggaraan PKM- pelatihan komunikasi krisis bagi para pelaku usaha wisata } \\
\text { kuliner ibu-ibu dari masyarakat setempat desa Denai Lama Wisata kuliner Paluh } \\
\text { Naga Kecamatan Pantai Labu Kabupaten Deliserdang }\end{array}$ \\
\hline 3 & $\begin{array}{l}\text { Penutupan PKM- pelatihan komunikasi krisis bagi para pelaku usaha wisata kuliner } \\
\text { ibu-ibu dari masyarakat setempat desa Denai Lama Wisata kuliner Paluh Naga } \\
\text { Kecamatan Pantai Labu Kabupaten Deliserdang. }\end{array}$ \\
\hline
\end{tabular}

PKM dimulai dengan paparan pentingnya pelatihan komunikasi krisis bagi para pelaku usaha wisata kuliner ibu-ibu dari masyarakat setempat saat pandemi covid19, (Su et al., 2021)Samad, Abdus mengatakan bahwa perlunya praktik komunikasi krisis efektif di desa Denai Lama Wisata kuliner Paluh Naga Kecamatan Pantai Labu dan pemberian materi Teknik menangani keluhan pelanggan yang bersifat case study serta paparan materi dasar sehingga dapat dipahami dengan mudah oleh para pelaku usaha wisata yang dominan dilakukan para ibu-ibu dari desa Denai Lama.

Materi yang diberikan dalam kegiatan PKM adalah materi yang bersifat routine and pattern yang berupa kosakata keseharian. Kegiatan ini dilaksanakan pada bulan Juni 2021. Pelaku usaha wisata Kuliner yang dominan dilakukan para ibu-ibu di desa Denai Lama diberikan pelatihan komunikasi krisis terkait penanganan keluhan wisatawan seminggu sekali selama bulan Juni 2021 dengan pemberian pengarahan sosialisasi case study untuk mengenalkan para ibu-ibu tentang wisaatawan yang mengeluhkan dari beberapa hal termasuk pelayanan prokes (protokol Kesehatan), citarasa maupun kesediaan guantity kuliner. Pada setiap pertemuan, mereka selalu diingatkan materi yang dipelajari sebelumnya dan point-point apa yang dianjurkan dan sesuatu yang tidak dianjurkan untuk dikatakan dalam menangani keluhan wisatawan, juga diberikan kesempatan untuk menirukan pengucapan dan memperaktekannya pada ruleplay (permainan) yang dapat meningkatkan motivasi mereka.

Pelaksanan kegiatan ini dilakukan oleh tim pengabdian dengan pokok bahasan yang disampaikan mengenai:

1. Penyampaian materi yang meliputi pentingnya dan manfaat komunikasi krisis menangani keluhan wisatawan dalam pelaksanaa usaha wisata saat pandemi covid19.

2. Penjelasan tentang Teknik menangani yang disarankan dan yang tidak disarankan dalam menangani keluhan wisatawan dalam pelatihan.

3. Penjelasan tentang pengembangan daerah wisata.

4. Pelatihan komunikasi krisis terkait penanganan keluhan wisatawan pada para ibuibu di lokasi wisata Paluh Naga yang disesuaikan dengan lingkungan sekitar dan karakteristik pengetahuan ibu-ibu untuk menciptakan proses pelatihan yang active learning sehingga pembelajaran bersifat pokus. 
5. Tanya jawab dengan peserta PKM terkait dengan materi yang disampaikan dalam pelatihan komunikasi krisis untuk menangani keluhan wisatawan.

Pelatihan Pengabdian Kemitraan Masyarakat yang dilaksanakan, nampak bahwa peserta PKM memahami penyampaian yang telah disampaikan oleh tim terkait dengan pelatihan komunikasi krisis dalam menangani keluhan wisatawan. PKM yang dilaksanakan menggugah antusias peserta untuk berkreasi dan termotivasi mencoba memahami dan mengidentifikasi sikap dari wisatawan yang mengeluh atas pelayanan prokes (protokol kesehatan), citarasa maupun kesediaan guantity yang menurut wisatawan belum effektif dan tepat.

PKM ini diharapkan dapat menambah pengetahuan, keterampilan dan lebih percaya diri saat menjalani tugas dilapangan ada wisatawan mengeluh dengan sesuatu yang tidak sesuai pada expektasi /harapan wisatawan. Para pelaku usaha wisata Paluh Naga akan lebih semangat dan termotivasi untuk menirukan dan mempraktekkan Teknik komunikasi krisis dalam melakasanakan usaha wisata.

Hasil pelatihan ini akan bermanfaat bagi Masyarakat Desa Denai Lama, Aparatur Pemerintah Desa, Khususnya pelaku usaha wisata dan Reputasi Destinasi Wisata Paluh Naga. Disamping itu dengan adanya pelatihan ini akan menambah semangat dan ketertarikan para pelaku usaha wisata untuk berusaha meningktakan pemahamannya dan percaya diri untuk menangani keluhan wisatawan.

Hasil kegiatan PKM pelatihan komunikasi krisis terkait menangani keluhan wisatawan oleh para pelaku usaha wisata secara komgaris besar mencakup beberapa komponen sebagai berikut:

a. Ketercapaian peserta pelatihan

b. Ketercapaian tujuan pelatihan

c. Ketercapaian target materi yang telah direncanakan

d. Antosias peserta dalam mengikuti rangkaian kegiatan PKM pelatihan komunikasi krisis dalam menangani keluhan wisatawan dalam ber wisata menikmati kuliner.

e. Kemampuan peserta dalam penguasaan materi

Dalam pelaksanaannya, kegiatan ini diikuti oleh para ibu-ibu pelaku usaha wisata kuliner Paluh Naga anak di desa Denai Lama Kecamatan Pantai Labu. Dengan demikian dapat dikatakan bahwa target peserta tercapai. Angka tersebut menunjukkan bahwa kegiatan ini dilihat dari jumlah peserta yang mengikuti dapat dikatakan berhasil.

Ketercapaian tujuan pelatihan komunikasi krisis terkait menangani keluhan wisatawan secara umum tergolong baik. Materi pelatihan yang direncanakan tersampaian kepada peserta pelatihan. Pelaku usaha wisata para ibu-ibu di desa Denai Lama Kecamatan Pantai Labu juga memiliki kesempatan untuk mempraktikkan cara menghadapi keluhan wisatawan secara lisan dan tulis; namun keterbatasan waktu yang disediakan mengakibatkan tidak semua materi tentang Teknik penanganan keluhan wisatawan dari mulai yang disarankan sampai yang tidak disarankan dapat disampaikan secara detil. Namun dilihat dari hasil latihan dan antusias para peserta maka dapat disimpulkan bahwa tujuan kegiatan ini dapat tercapai.

Ketercapaian target materi pada kegiatan PKM dengan materi komunikasi krisis seperti yang dikatakan (Faustyna, 2020) Faustyna, saat krisis terjadi manfaatkan model komunikasi Krisis untuk menanggulanginya; (Salma, 2018) Salma, sebelum, saat dan sesudah krisis, media internate dapat menjadi suatu solusi;

@ 2021 Bima Abdi (https://bimaberilmu.com/jurnal/index.php/bp-jpm) 
(Faustyna et al., 2019a) Faustyna; krisis komunikasi dapat menjadi sesuatu yang menurunkan reputasi (Faustyna et al., 2019b)Faustyna, komunikasi krisis telah bermanfaat pada wisata kuliner malam di lokasi wisata Merdeka Walk Medan (faustyna, 2020)Faustyna, Badan Usaha Milik Desa menjadi salah satu lembaga solusi yang dapat mendampingi pelaku usaha wisata (Nahar, 2020) L.Nahar, pemerintah sudah melakukan komunikasi krisis saat pandemi Covid19 melanda Dunia (Kartawidjaja, 2020) J. Kartawidjaja, komunikasi Publik juga dapat menjadi solusi (Coombs, 2007) W. T. Coombs. reputasi dijaga saat krisis melanda untuk menghadapi saat pandemic covid19, terkait menangani keluhan wisatawan (Supriyanto, 2019) W. Supriyanto, menurutnya bahwa keluhan pealnggan dapat diatasi dengan komunikasi dilembaga secara rutin; (Setiadi \& Wahyudi, 2020) B. Setiadi and J. Wahyudi, keluhana pelanggan baiknya di kolek dan dimonitor selanjutnya dicarikan solusi (Samad, 2013) B. Setiadi and J. Wahyudi, keluhan pelanggan dapat selesai dengan memanaje keluhan dengan baik; Pelatihan ini secara umum tergolong baik karena materi pendampingan telah dapat disampaikan secara keseluruhan dan dapat dipahami dengan baik oleh peserta pelatihan yang dibuktikan dengan pertanyaan yang disampaikan, serta respon yang diberikan baik respon secara verbal maupun non-verbal. Keberhasilan ini selain diukur dari komponen di atas, juga dapat dilihat dari kepuasan peserta setelah mengikuti kegiatan.

Kegiatan ini dapat memberikan pemahaman dan kemampuan menangani keluhan wisatawan bagi pelaku usaha wisata dan masyarakat di desa Denai Lama Kecamatan Pantai Labu, Selain itu, mereka akan memahmi pentingnya menjaga reputasi wisata Paluh Naga dari kesan negative yang diberikan para wisatawan yang mengeluh terkait pelayanan prokes (protokol kesehatan), citarasa maupun kesediaan guantity kuliner.

\section{KESIMPULAN}

Dari hasil dan pelaksanaan kegiatan PKM pelatihan komunikasi krisis terkait menangani keluhan wisatawan Pelaku usaha wisata para ibu-ibu di desa Denai Lama Kecamatan Pantai Labu dapat disimpulkan bahwa PKM ini diselenggarakan dengan baik dan berjalan dengan lancar sesuai dengan rencana kegiatan yang telah disusun meskipun belum semua peserta pendampingan menguasai dengan baik materi yang disampaikan.

Kegiatan ini mendapat sambutan sangat baik terbukti dengan keaktifan peserta mengikuti pendampingan dengan tidak meninggalkan tempat sebelum waktu pelatihan berakhir. Berdasarkan evaluasi yang telah dilakukan disarankan adanya kegiatan lanjutan yang berupa pelatihan sejenis untuk diselenggarakan secara periodic sehingga pelaku usaha wisata dapat memahami apa yang dibutuhkan wisatawan. Pelaku usaha dalam menjalankan usaha wisatanya dapat berkomunikasi secara effektif

\section{DAFTAR PUSTAKA}

Coombs, W. T. (2007). Protecting Organization Reputations During a Crisis: The Development and Application of Situational Crisis Communication Theory. Corporate Reputation 10(3), Review, 163-176. https://doi.org/10.1057/palgrave.crr.1550049 
faustyna. (2020). BINCANG-BINCANG SEPUTAR BUMdesa TEMA : " P erspektif Komunikasi Krisis pada Kompetensi Pelaku Bumdesa dan Visi Misi Lembaga pada P andemi covid19" JUDUIl ARTIKEL Strategy Komunikasi Krisis era new normal covid19 PBI Dr. FAUSTYNA S . Sos ., M . M ., M . 0-6.

Faustyna. (2020). Coordination of Communication Crisis Model 1. Indonesian Journal of Education, Social Sciences and Research (IJESSR) Vol. 1, No. 2, $\begin{array}{llllll}\text { September 2020, } & \text { Pp. 79 86 ISSN:, }\end{array}$ http://jurnal.umsu.ac.id/index.php/ijessr

Faustyna, Erdiana, L. K., Hafiar, H., \& Bakti, I. (2019a). Communication crisis in tourism office: Negative news by online media. Library Philosophy and Practice, 2019, 1-20.

Faustyna, Erdiana, L. K., Hafiar, H., \& Bakti, I. (2019b). Evening culinary tourism: The publicity of Merdeka Walk medan. International Journal of Civil Engineering and Technology, 10(2), 2213-2226.

Kartawidjaja, J. (2020). Komunikasi Publik di Masa Pandemi Covid-19 Ibnu. Orphanet Journal of Rare Diseases, 21(1), 1-9.

Nahar, L. (2020). KOMUNIKASI KRISIS PEMERINTAH INDONESIA MENGHADAPI PANDEMI COVID-19. Jurnal Syntax Admiration.

Salma, A. N. (2018). S Trategi K Omunikasi K Risis Di E Ra D Igital : P Enggunaan I Nternet Dari Sebelum Hingga Sesudah Krisis C Risis C Ommunication S Trategy in D Igital a Ge:

Samad, A. (2013). MANAJEMEN KELUHAN PELANGGAN PERUSAHAAN DAERAH AIR MINUM TIRTA SATRIA KABUPATEN BANYUMAS CUSTOMER. Journal of Chemical Information and Modeling, 53(9), 16891699.

Setiadi, B., \& Wahyudi, J. (2020). APLIKASI MONITORING PENGADUAN DAN KELUHAN PELANGGAN PADA PT. PLN (Persero) AREA BANJARMASIN BERBASIS WEB. Technologia: Jurnal Ilmiah, 11(4), 234. https://doi.org/10.31602/tji.v11i4.3646

Su, Z., McDonnell, D., Wen, J., Kozak, M., Abbas, J., Šegalo, S., Li, X., Ahmad, J., Cheshmehzangi, A., Cai, Y., Yang, L., \& Xiang, Y. T. (2021). Mental health consequences of COVID-19 media coverage: the need for effective crisis communication practices. Globalization and Health, 17(1), 1-8. https://doi.org/10.1186/s12992-020-00654-4

Supriyanto, W. (2019). Strategi Komunikasi Internal PDAM Tirta Satria Mengatasi Keluhan Pelanggan. Warta ISKI, 2(01), 48-53. https://doi.org/10.25008/wartaiski.v2i01.27 